\title{
LEADING SYSTEMS AND VIABILITY OF CITRIC BUDS IN HYDROPONICS ${ }^{1}$
}

\author{
WIARA DE ASSIS GOMES ${ }^{2 *}$, NILTON NAGIB JORGE CHALFUN ${ }^{3}$, PEDRO MARANHA \\ PECHE $^{3}$, JOSÉ DARLAN RAMOS ${ }^{3}$, VALDEMAR FAQUIN $^{4}$
}

\begin{abstract}
The purpose of this experiment was to evaluate the production of budstocks and the viability of the buds of the 'Valencia' and 'Pera' orange tree varieties in a hydroponic system. The experiment was arranged in a completely randomized design in a $2 \times 3$ factorial scheme. The two orange varieties were grafted onto the Rangpur lime tree with three leading systems (single stem, two stems, and three stems) and three replications of 10 plants per plot. The time that elapsed between pruning the stems at $40 \mathrm{~cm}$ and the first collection, as well as the time between each harvest were determined. The number of buds in the median part of the stems and percentage of viable buds in each leading system were also measured. This was determined after performing inverted $\mathrm{T}$ budding on the Rangpur lime tree rootstocks and verifying that the procedure was successful. The production of citrus plant budstocks is feasible in a hydroponic system.
\end{abstract}

Keywords: Budstocks. Greenhouse. Parent plants.

\section{SISTEMAS DE CONDUÇ̃̃O DE PLANTAS BORBULHEIRAS CÍTRICAS EM HIDROPONIA}

RESUMO - Objetivou-se, com o presente experimento, avaliar a produção de hastes porta-borbulha e a viabilidade de suas borbulhas nas variedades de laranjeira 'Valência' e 'Pera' em sistema hidropônico. Usou-se delineamento inteiramente casualizado, arranjado em esquema fatorial $2 \times 3$, sendo duas variedades copa foram às laranjeiras 'Valência' e 'Pera' enxertadas sob o limoeiro Cravo, e três sistemas de condução: haste única, duas e três hastes, com três repetições 10 plantas por parcela. Determinou-se o tempo transcorrido entre a poda de ramificação a $40 \mathrm{~cm}$, e a primeira colheita de hastes porta-borbulha, bem como o tempo entre cada colheita, por 12 meses, mensurando-se ainda o número de borbulhas na porção mediana dos ramos, bem como a percentagem de borbulhas viáveis de cada sistema de condução, a qual foi determinada após realização de enxertia tipo $\mathrm{T}$ invertido em porta enxertos de limão 'Cravo' e a constatação do sucesso de tal operação. A produção de plantas borbulheiras de citros em sistema hidropônico é viável.

Palavras-chave: Hastes porta-borbulhas. Ambiente protegido. Plantas matrizes.

\footnotetext{
${ }^{*}$ Corresponding author

${ }^{1}$ Received for publication in $07 / 18 / 2017$; accepted in $01 / 25 / 2019$.

Paper extracted from the doctoral thesis of the first author.

${ }^{2}$ Jundiaí Agricultural School, Academic Unit Specializing in Agrarian Sciences, Universidade Federal do Rio Grande do Norte, Macaíba, RN, Brazil; wiaracastelo@hotmail.com - ORCID: 0000-0001-9550-6976.

${ }^{3}$ Departament of Agriculture, Universidade Federal de Lavras, Lavras, MG, Brazil; nchalfun@dag.ufla.br - ORCID: 0000-0002-03494523, pedmpeche@hotmail.com - ORCID: 0000-0001-8865-1702, darlan@dag.ufla.br - ORCID: 0000-0002-0963-8831.

${ }^{4}$ Departament of Soils, Universidade Federal de Lavras, Lavras, MG, Brazil; vafaquin@dcs.ufla.br - ORCID: 0000-0002-4204-6782.
} 


\section{INTRODUCTION}

Seedlings are the most important input for implementing a citrus orchard, due to the need for obtaining quality genetic material. According to some specialists, seedlings are the foundation of the commercial citrus orchard.

From the beginning, citrus propagation used seeds. Around 1900, with the advent of budstock grafting, a great advance occurred in the vegetative propagation of citriculture. Since then there has been a constant attempt to improve seedling quality. It should be emphasized that the citrus seedling is formed of two different genotypes, the rootstock, responsible for the root system, and canopy, the variety of commercial interest.

One of the systems advocated to improve seedling quality was densified planting called budstocks. As technology evolved and higher requirements were set by the enforcement agencies, it was advocated that the system of densified plants protected under screens, to produce budstocks, would be satisfactory. This system was introduced in Brazil from 1984 onwards, favoring the faster multiplication of budstocks with a quality desirable for grafting and the maintenance of the parent plant without excessive cutting, with an additional possibility for the periodical evaluation of faithfulness and fruit production quality (CARVALHO et al., 2001). Despite these advantages, it must be considered that the quantity and offer of budstock stems is seasonal, since its buds have an appropriate point of maturity at which they are picked (ROMEIRO et al., 2001).

Alternatives to improve the system have been tested, and hydroponic cultivation may be a solution. This technology has been tested, with relative success, to produce seedlings of forest species, passion fruit, strawberry, and tobacco, as well as to produce leaves, fruits, and ornamental plants. Recently, a modified hydroponic cultivation methodology was proposed by Faquin and Chalfun (2008), and tested by Souza et al. (2011a), to produce pear tree, peach tree (SOUZA et al., 2011b), and 'Ponkan' tangerine seedlings (SOUZA, et al., 2013), and its application was found to be completely feasible.

The purpose of this experiment was to evaluate the production of budstocks and the viability of the buds of the 'Valencia' and 'Pera' orange tree varieties in a hydroponic system.

\section{MATERIAL AND METHODS}

The study was performed, in 2012, in the
Hydroponics Sector of the Soil Sciences Department at the Federal University of Lavras - UFLA, state of Minas Gerais (MG), Brazil. The climate in that municipality is of the Cwb type, according to the Köppen classification system. The structure of the hydroponics system and the nutrient solution used in the experiment were proposed by Faquin and Chalfun (2008). Throughout the experiment the 'Citropotes' remained on appropriate supports, under hydroponic conditions in greenhouses, arranged in level shallow containers, called "trays," where they received a nutrient solution. These containers were connected to a reservoir containing $1000 \mathrm{~L}$ of the nutrient solution, whose circulation was actuated by a timer at 15 min intervals and regulated by a motor pump connected to the reservoir. The excess nutrient solution in the trays returned to the reservoir by gravity, through appropriate piping. Nutrient replacement in the reservoir solution was performed through electric conductivity and the value was adjusted daily by adding stock solutions of macro and micronutrients. The $\mathrm{pH}$ of the nutrient solution was kept between 5.5 and 6.5 . The changes to the nutrient solution were performed periodically, every 30 days.

Certified seeds of Rangpur lime were acquired for the experiment. They were previously washed, treated, and disinfested, and later sown in tubs of $288 \mathrm{~mL}$ capacity, containing Vermiculita ${ }^{\circledR}$, and 2 seeds with tegument were placed in each tub. After germination, when the plantules were $10 \mathrm{~cm}$ high, they were thinned out leaving the more vigorous individuals. When the plants reached $15 \mathrm{~cm}$ they were transplanted into plastic bags with a $4 \mathrm{~L}$ capacity, containing Plantmax ${ }^{\circledR}$. On reaching the grafting point, considered between 5 and $6 \mathrm{~mm}$ when measured $10 \mathrm{~cm}$ from the soil, they were grafted with certified buds of the 'Pera' and 'Valencia' orange varieties. After grafting, the rootstocks were decapitated $5 \mathrm{~cm}$ from the grafting point.

After the success of the grafting was confirmed, the buds were managed on a single stem until they became $15 \mathrm{~cm}$ long. Next, they were transplanted into 'Citropote' type tubs, with $4.8 \mathrm{~L}$ of the commercial substrate, Vermiculite, and transferred to the modified hydroponic system. After the buds reached $40 \mathrm{~cm}$, the stems were pruned, and budding was conducted so that there would be canopies with one, two, and three stems per plant.

The test was arranged in a completely randomized design, with treatments organized in a 2 $\times 3$ factorial scheme. The varieties of canopies, the 'Pera' and 'Valencia' orange trees, were grafted onto the 'Cravo' lemon tree. There were three leading systems, single stem, two stems, and three stems (Figure 1), with three replications of 10 plants per plot. 


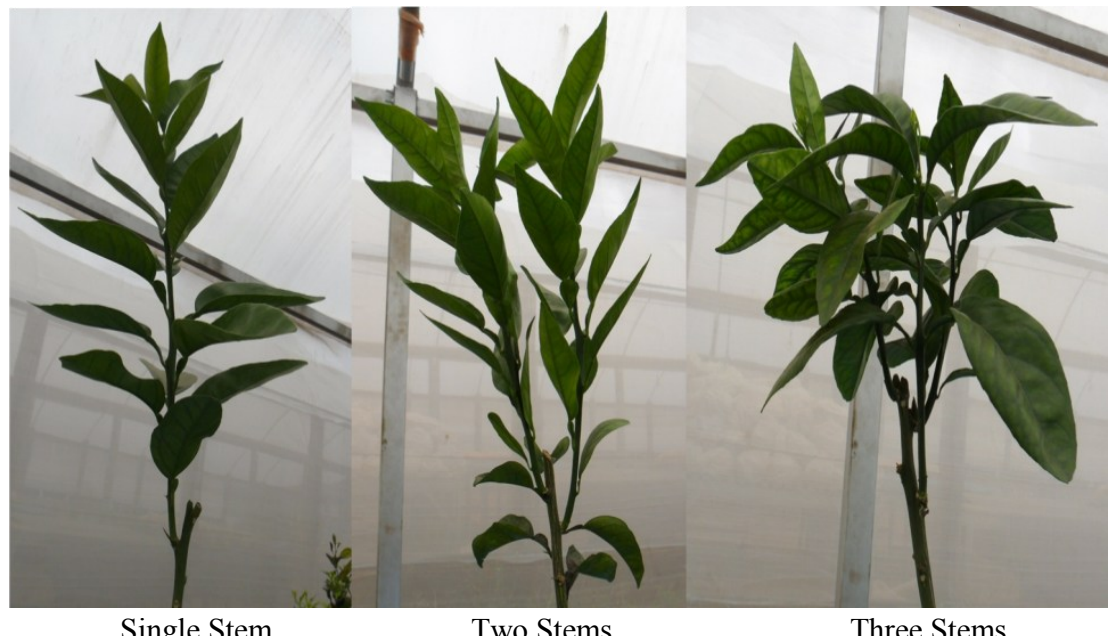

Figure 1. Leading systems for the parent plant buds of the 'Pera' and 'Valencia' orange trees in a modified hydroponics system.

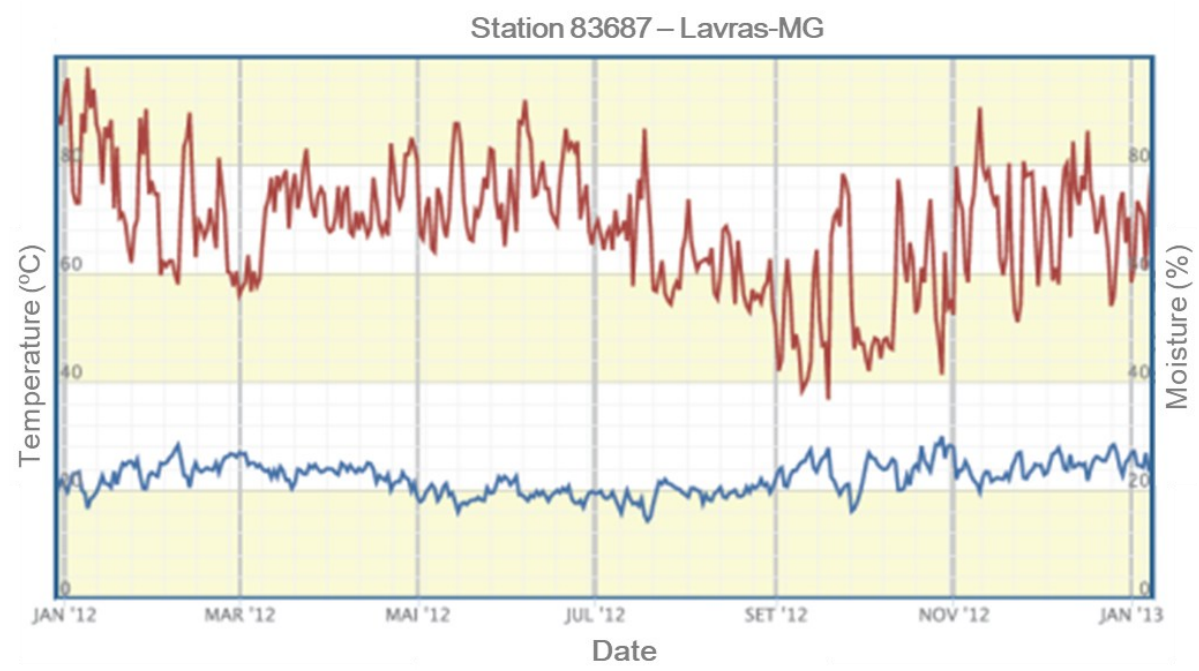

Figure 2. Temperatures recorded during the experimental period (INMET, 2013).

The evaluations began by determining the time that elapsed between pruning the stems at $40 \mathrm{~cm}$ and the first harvest of the stems, as well as the time between each harvest for 12 months. Immediately after harvesting, the leaves were removed, the stems were then washed in water and disinfested by immersion in a sodium hypochlorite solution with $1 \%$ active chlorine, for $15 \mathrm{~min}$, and washed again in water. After this procedure, the number of buds in the medium portion of these stems was measured; the percentage of viable buds of each leading system was determined after an inverted $\mathrm{T}$ type graft was performed on a 'Cravo' lemon rootstock. The success of this procedure was verified by the growth of the sprouts. The data was submitted to an analysis of variance using Tukey's test, with a $5 \%$ probability of error, to compare the means, using the Sisvar application (FERREIRA, 2011).

\section{RESULTS AND DISCUSSION}

In the modified hydroponic system, according to the individual capacity of each tray, the parent plants produced $36.15 \mathrm{buds} / \mathrm{m}^{2}$. In a conventional system, the area needed to produce the parent plants for buds varies according to the container used. In this case, it is advisable to use $20 \mathrm{~L}$ plastic containers (buckets) or $100 \mathrm{~L}$ containers (carboys), placed directly in the soil. In the latter case it is necessary to have a working area of $6.33 \mathrm{~m}^{2}$ to produce the same number of parent plants as in this experiment. Thus, it is emphasized that there is a better use of area, with hydroponic cultivation, under the conditions described in this study.

The time that elapsed between the stem pruning and first budstock harvest was 60 days and 14 months after sowing the rootstock (Figure 3). 

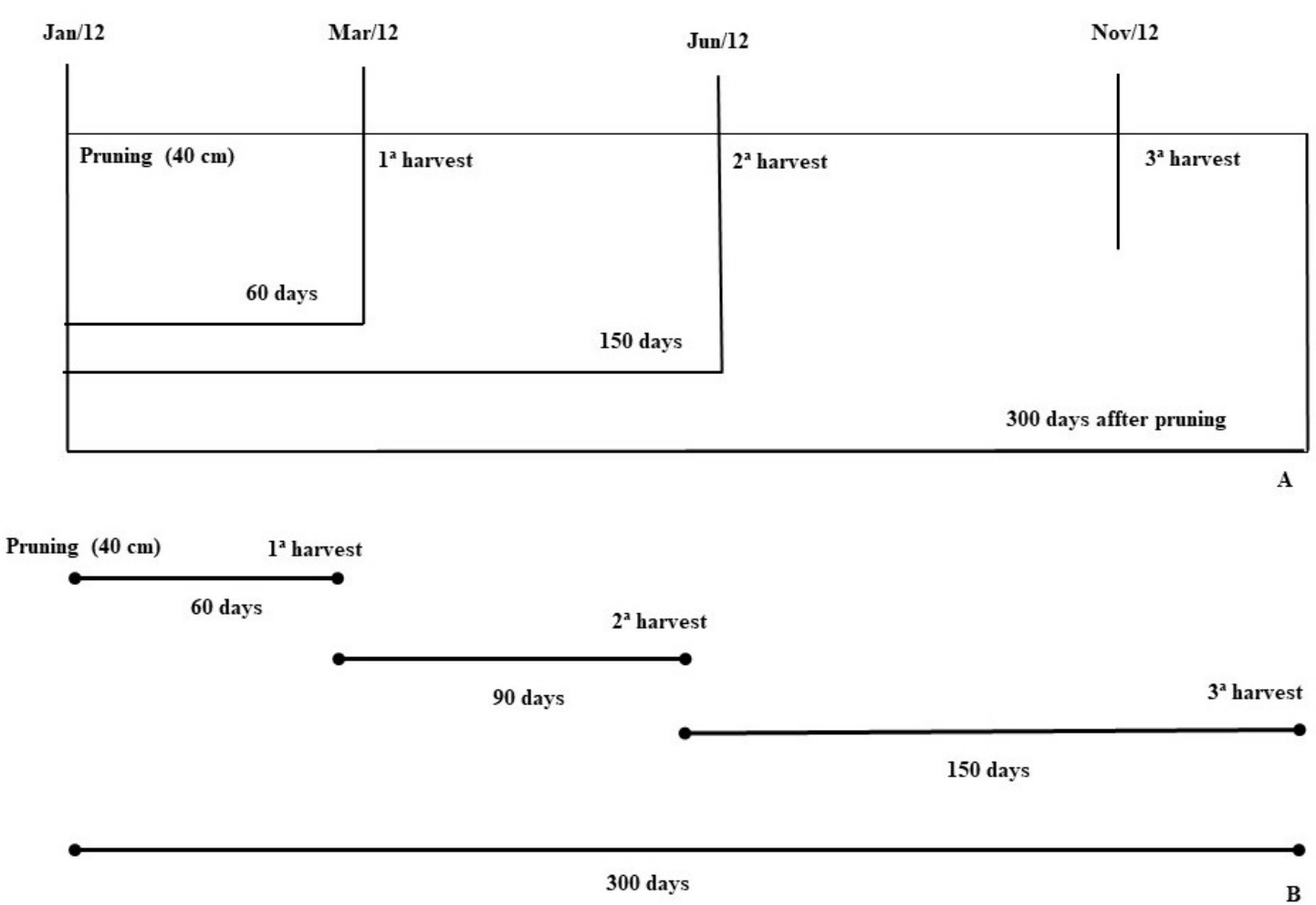

Figure 3. Chronology of the production of budstock stems of the 'Pera' and 'Valencia' orange trees, in a modified hydroponic system. A: days after pruning; B: interval between the harvests in days.

Generally, according to Oliveira (2009), the first cutting of the buds can be performed from 15 to 24 months after sowing the rootstocks, depending on the climatic conditions in the region and the plant leading system. However, that publication emphasizes that it takes about 60 to 90 days for buds to mature, and therefore, the stems from the first harvest of the present study were already mature. Maciel, Souza and Schäfer, (2008), who evaluated the viability of buds from the 'Valencia' orange and 'Montenegrina' tangerine trees, under the different disinfection and storage processes in a cold chamber, used stems with a mean age of 180 days. Siqueira et al. (2010) used stems with a mean age of 120 days to determine the maintenance of the viability of buds from the 'Baianinha' and 'Pera Rio' orange trees. Furthermore, from analyzing Figure 2 it can be seen that in a 10-month period, or 300 days after grafting, 3 harvests of budstock stems were possible in the three systems proposed. However, it was observed that a longer time elapsed between the harvests, as it increased from 90 days from the first to the second, and an additional 150 days to the third. This increase may have been due to the reduction in the mean temperature that occurred during the $2^{\text {nd }}$ semester of 2012 (Figure 2). Thus, the lower temperatures may have reduced the vegetative development of the plants, resulting in a lower growth of the budstock stems during this period.

When the number of buds per stem was analyzed, it was found that there was no significant difference between the varieties of the orange trees and number of stems. However, as expected, the leading systems with two and three stems had a significantly higher number of buds per stem than the single stem system (Table 1). In a study performed by Siqueira et al. (2010), to determine the maintenance of the viability of buds from the 'Baianinha' and 'Pera Rio' orange trees in refrigerated storage, the stems had an average 10 buds in their median portion, which is in accordance with the results of this study, which was 10.61 buds per stem on average. Additionally, according to Oliveira (2009), the work life of a parent plant for buds is five years from the time that grafting is performed. 
Table 1. Number of buds per stem produced in different plant leading systems for bud plants of the 'Pera' and 'Valencia' orange trees, in a modified hydroponic cultivation.

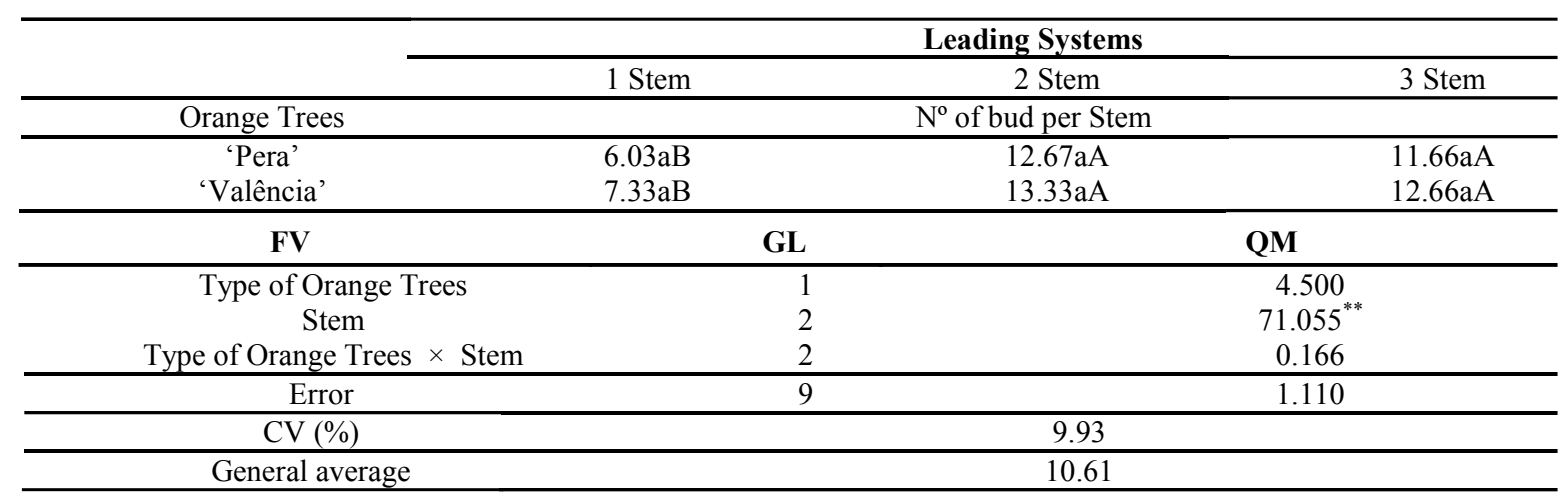

Means followed by the same lowercase letters in the columns and uppercase letters in the rows are not significantly different, according to Tukey's test at $1 \%$ probability. $* *$ Significant at $1 \%$ probability according to the $\mathrm{F}$ test.

The budstock stems from the first harvest were not used in the viability test, instead serving as a foundation to train the following harvests. When the viability of the buds was analyzed after an inverted T graft in 'Cravo' lemon trees, there was a significant interaction between the leading systems and the varieties tested; therefore, the factors were analyzed as an ensemble (Table 2).

For the 'Pera' variety, the greatest bud viability was obtained in the two stem leading system. The 'Valencia' variety presented greater viability when grafted on a single stem. The three- stem leading system proved the same for the two varieties studied. Siqueira et al. (2010) observed an increased viability for grafting of the 'Pera Rio' cultivar and a reduced viability of the buds of 'Baianinha' orange trees when stored for a long time. Araújo and Siqueira (2008) evaluated the effectiveness of several methods for forcing the budding of the yolk of just grafted citrus, for which the bud viability was reduced only when ringing was used together with the removal of the rootstock leaves.

Table 2. Viability of the buds (\%) produced in different leading systems of the 'Pera' and 'Valencia' orange trees, in modified hydroponic cultivation.

\begin{tabular}{|c|c|c|c|c|}
\hline & \multicolumn{4}{|c|}{ Leading Systems } \\
\hline & 1 Stem & & & 3 Stem \\
\hline Orange Trees & \multicolumn{4}{|c|}{ Viability of buds (\%) } \\
\hline $\begin{array}{l}\text { 'Pera' } \\
\text { 'Valência' }\end{array}$ & $\begin{array}{l}37.67 \mathrm{cB} \\
87.67 \mathrm{aA}\end{array}$ & \multicolumn{2}{|c|}{$\begin{array}{l}84.33 \mathrm{Aa} \\
53.00 \mathrm{cB}\end{array}$} & $\begin{array}{l}74.00 \mathrm{Ab} \\
73.67 \mathrm{Ab}\end{array}$ \\
\hline FV & \multicolumn{4}{|c|}{ QM } \\
\hline Type of Orange Trees & \multicolumn{4}{|c|}{168.05} \\
\hline Stem & \multicolumn{4}{|c|}{187.38} \\
\hline Type of Orange Trees $\times$ Stem & \multicolumn{4}{|c|}{$2527.38 * *$} \\
\hline Error & \multicolumn{4}{|c|}{9.726} \\
\hline $\begin{array}{c}\text { CV }(\%) \\
\text { General average }\end{array}$ & \multicolumn{4}{|c|}{$\begin{array}{c}4.56 \\
68.39\end{array}$} \\
\hline
\end{tabular}

Means followed by the same lowercase letters in the columns and uppercase letters in the rows are not different, according to Tukey's test at $1 \%$ probability. ${ }^{* *}$ Significant at $1 \%$ probability according to the $\mathrm{F}$ test.

\section{CONCLUSIONS}

The production of citrus budding plants is feasible in a modified hydroponic system.

Bud viability was affected by the systems in the two varieties of orange tree studied. It is likely most appropriate to train in two or three stems of the 'Pera' orange tree and in one or three stems of the 'Valencia.'

\section{REFERENCES}

ARAÚJO, R. F.; SIQUEIRA, D. L. Avaliação de métodos de forçamento de brotação de borbulhas em citros. Revista Ceres, v. 55, n. 5, p. 450-454, 2008.

CARVALHO, S. A. et al. Produção de borbulha básica para formação de mudas de citros sadias em São Paulo. Laranja, v. 22, n. 1, p. 185-201, 2001.

FAQUIN, V.; CHALFUN, N. N. J. Hidromudas: 
Processo de produção de porta-enxerto de mudas frutíferas, florestais e ornamentais enxertadas em hidroponia. BRN. PI 0802792-7. 2008. Disponível em: $\quad<$ http://www.inpi.gov.br/menu-superior/ pesquisas $>$. Acesso em: 28 jun. 2012.

FERREIRA, D. F. Sisvar: A computer statistical analysis system. Ciência e Agrotecnologia, v. 35, n. 6, p. 1039-1042, 2011.

MACIEL H. S.; SOUZA, P. V. D.; SCHÄFER, G. Viabilidade de borbulhas de citros coletadas de ambiente protegido e mantidas em frigoconservação. Revista Brasileira de Fruticultura, v. 30, n. 1, p. 241-245, 2008.

OLIVEIRA, R. P. et al. Sistemas de Produção 15: Borbulhas de Citros. EMBRAPA: Pelotas-RS. 2009. $41 \mathrm{p}$.

ROMEIRO, S. et al. Embalagem e tratamento químico na conservação de ramos porta-borbulhas de laranjeira 'Natal' em câmara fria. Laranja, v. 22, n. 2, p. 425-433, 2001.

SIQUEIRA, D. L. et al. Viabilidade de hastes portaborbulhas de citros em diferentes estádios de desenvolvimento e períodos de armazenamento. Revista Ceres, v. 57, n. 1, p. 103-111, 2010.

SOUZA, A. G. et al. Production of pear grafts under hydroponic conditions. Scientia Agraria, v. 12, n. 1, p. 266-268, 2011a.

SOUZA, A. G. et al. Production of peach grafts under hydroponic conditions. Ciência e Agrotecnologia, v. 2, n. 2, p. 322-326, 2011 b.

SOUZA, A. G. et al. Produção de mudas de tangerineira 'Ponkan' em sistema hidropônico. Revista Ciência Agronômica, v. 44, n. 4, p. 902909, 2013. 